\title{
In vitro potential of Paenibacillus alvei DZ-3 as a biocontrol agent against several phytopathogenic fungi
}

\author{
Natalija Atanasova-Pancevska*, \\ Dzoko Kungulovski \\ Department of Microbiology \\ and Microbial Biotechnology, \\ Faculty of Natural Sciences \\ and Mathematics, \\ Institute of Biology, \\ Ss. Cyril and Methodius University, \\ Arhimedova 5, P.O. Box 162, \\ Skopje 1000, Macedonia
}

Fungal phytopathogens cause significant losses in many economically important crops and vegetables. One way to control these devastating pathogens is using higher doses of fungicides that not only increase the cost of production but also cause significant damage to the environment. Consequently, there is an increasing demand from consumers and officials to reduce the use of chemical pesticides. In this context, biological control through the use of natural antagonistic microorganisms has emerged as a promising alternative.

The goal of this paper is to evaluate environmentally-friendly treatment for in vitro control of some fungal phytopathogens.

In the present study, the bacterial strain DZ-3, which shows strong antifungal activity, was isolated from the samples of rotten apple compost from the composting plant in Resen, Macedonia, and identified as Paenibacillus alvei according to morphological and taxonomic characteristics and 16S rRNA gene sequence analysis.

As test microorganisms, we used Botrytis cinerea FNSFCC 23, Fusarium oxysporum FNS- FCC 103, Plasmopara viticola FNS- FCC 65, Alternaria alternata FNS- FCC 624, but also Aspergilus ochraceus FNS- FCC 46, Aspergilus niger FNS- FCC 142, and Penicillium commune FNS- FCC 864.

The effect of Paenibacillus alvei DZ-3 on growth of the tested fungi was evaluated by the dual culture technique and disc diffusion method. Clear inhibition zones were observed in all test microorganisms.

The above-described results indicate that Paenibacillus alvei DZ-3 may have the potential as a biocontrol agent to control various phytopathogenic fungi.

Keywords: phytopathogen, Paenibacillus alvei, antifungal activity, compost

The paper was presented at the "Smart Bio" conference event held in Kaunas, 18-20 May 2017. 


\section{INTRODUCTION}

Plant diseases caused by different organisms are one of major problems all over the world. These plant-disease organisms are responsible not only for plant diseases in different plants, but also cause significant economic losses in plantation. Chemical control is usually used as a basic strategy for disease control.

Extensive use of chemical agents causes several negative effects, such as development of pathogen resistance to the applied agents and their environmental impacts (Compant et al., 2005). There is an increasing demand for finding more effective and safer methods to control plant pests. One way to achieve this is finding an effective biocontrol agent against disease-causing organisms in agricultural areas and in this way decreasing the hazardous effects of chemical insecticides to the environment and other living organisms. Biological control is a method of controlling pests such as insects, mites, weeds and plant diseases using other organisms.

As the most common plant pathogens, phytopathogenic fungi are capable of infecting different types of plants. Resistance of fungal pathogens to biocontrol microorganisms has not been reported and is considered an environmentalfriendly approach (Eziashi et al., 2007).

The genus Paenibacillus, originally included within the Bacillus and reclassified as a separate genus (Ash et al., 1993), is prevalently distributed in different soils and plant rhizospheres (Berge et al., 2002; von der Weid et al., 2002; Garbeva et al., 2003; Yoon et al., 2003). Different species of Paenibacillus have been demonstrated as having potential antifungal activities (Fortes et al., 2008; He et al., 2007; Liu et al., 2008; Raza et al., 2008; von der Weid et al., 2003; von der Weid et al., 2005).

The objective of the present study was to evaluate the biocontrol efficacy of Paenibacillus alvei DZ-3 from a compost sample against several plant pathogenic fungi in vitro.

\section{MATERIALS AND METHODS}

\section{Pathogenic fungal strains}

Different phytopathogenic fungi were used in this study as test fungi: a - Botrytis cinerea FNS- FCC 23, Fusarium oxysporum FNS- FCC 103, Plasmopara viticola FNS- FCC 65, Alternaria alternata FNS- FCC 624,

b - but also Aspergilus ochraceus FNSFCC 46, Aspergilus niger FNS- FCC 142 and Penicillium commune FNS- FCC 864.

All test fungi were part of the Culture Collection of the Department of Microbiology and Microbial Biotechnology, Faculty of Natural Sciences and Mathematics, Skopje, Macedonia.

\section{Collection of samples}

During the autumn of 2015, different samples of rotten apple compost from the composting plant in Resen, Macedonia, were collected for the isolation of the most potent Gram-positive antifungal bacterium.

\section{Isolation and identification of the bacterium}

Serial dilutions were prepared for each sample ( 1 gram of the sample diluted in $9 \mathrm{ml}$ of sterile distilled water, then $1 \mathrm{ml}$ of this dilution added to another $9 \mathrm{ml}$ of distilled water and the sequence was repeated until we reached the dilution of $10^{-5}$ ), then $0.1 \mathrm{ml}$ of the dilutions $10^{-4}$ and $10^{-5}$ of each sample was cultured on a $9 \mathrm{~cm}$ Petri dish of Mueller-Hinton agar and incubated at $30^{\circ} \mathrm{C}$ for 24 hours. After that each different single colony was tested against three test fungi, and the most potent antifungal bacterial isolate was taken and recultured for identification and further studies.

The isolate that showed preliminary antifungal activities was subjected to several microscopic tests (shape of cells, shape of spores, swelling of cells), morphological tests (colour, size of colonies, edge of colonies, consistency of colonies etc.), and 16S rRNA gene sequence analysis.

\section{Identification of the microorganisms by the $16 \mathrm{~S}$ rRNA sequencing technique}

First, DNA from the bacterial strain was isolated. A pure colony was grown overnight in the appropriate medium, cells were harvested by centrifugation (14000 rpm, $10 \mathrm{~min}$ ), washed twice with $1 \times$ PBS buffer $(140 \mathrm{mM} \mathrm{NaCl}, 2.7 \mathrm{mM} \mathrm{KCl}$, $100 \mathrm{mM} \mathrm{Na}{ }_{2} \mathrm{HPO}_{4}, 1.8 \mathrm{mM} \mathrm{KH} \mathrm{PO}_{4}, \mathrm{pH} 7.3$ ) and kept at $-20^{\circ} \mathrm{C}$ until further processing. DNA 
extraction was done using PrepManUltra reagent (Applied Biosystems), following the protocol for culture broth samples. The concentration of DNA was determined spectrophotometrically. DNA working solution of $2.7-3.1 \mathrm{ng} / \mu \mathrm{l}$ was prepared by diluting the stock DNA. The sequence of the $16 \mathrm{~S}$ ribosomal RNA gene (rDNA) of bacterial strain was determined using MicroSeq Full Gene Kit (Applied Biosystems), composed of two parts: MicroSeq ${ }^{\oplus}$ Full Gene $16 \mathrm{~S}$ rDNA Bacterial Identification PCR Kit and MicroSeq ${ }^{\oplus}$ Full Gene 16S rDNA Bacterial Identification Sequencing Kit. Amplification of the three fragments of the $16 \mathrm{~S}$ ribosomal RNA gene was done using $7.5 \mu \mathrm{l}$ DNA working solution in a reaction volume of $15 \mu \mathrm{l}$ on 2720 Thermal Cycler (Applied Biosystems). Purification of the amplified products was done using ExoSAP-IT ${ }^{\oplus}$ reagent (USB) according to the manufacturer's instructions prior to sequencing. The cycle sequencing was performed with forward and reverse primers for each amplified product according to the instructions provided by the kit with one exception: the final volume of the sequencing reactions was $10 \mu$ l.

After cycle sequencing, excess dye terminators and primers were removed from the cycle sequencing reactions by precipitation in separate tubes with $2 \mu \mathrm{l} 5 \mathrm{M} \mathrm{Na}$-acetate and $50 \mu \mathrm{l}$ ethanol. After incubation at room temperature for $30 \mathrm{~min}$, the tubes were centrifuged at $14000 \mathrm{rpm}$ for $30 \mathrm{~min}$, the supernatant was discarded, the precipitate was dried for $5 \mathrm{~min}$ at room temperature, and re-suspended in $20 \mu \mathrm{l}$ of $\mathrm{Hi}^{-\mathrm{Di}^{\mathrm{m}}}{ }^{\mathrm{T}}$ Formamide. Sequence analyses were performed on a 3500 Genetic Analyzer (Applied Biosystems).

\section{Antifungal bioassay tests}

Standardization of bacterial inoculum

The selected bacterial strain was grown in $10 \mathrm{ml}$ of Muller Hilton Broth (MHB) medium for $24 \mathrm{~h}$ at $37^{\circ} \mathrm{C}$. The turbidity of the resulting suspension was diluted with MHB medium to obtain approximately $1.5 \times 10^{8} \mathrm{CFU} / \mathrm{ml}$. This was done by measuring the absorbance at a $625 \mathrm{~nm}$ wavelength using a spectrophotometer. The acceptable range of the turbidity standard was
$0.08-0.10$. The turbidity of bacterial suspension is comparable to $0.5 \mathrm{McF}$ arland turbidity standards $(0.05 \mathrm{ml}$ of $1.175 \%$ Barium chloride $\left(\mathrm{BaCl}_{2} \times 2 \mathrm{H}_{2} \mathrm{O}\right)$ in $9.95 \mathrm{ml}$ of $1 \%$ Sulphuric acid $\left(\mathrm{H}_{2} \mathrm{SO}_{4}\right)$ ). This level of turbidity is considered equivalent to approximately $1.5 \times 10^{8} \mathrm{CFU} / \mathrm{ml}$.

\section{Standardization of fungal inocula}

The cultures of select pathogenic fungi were grown on Petri plates containing Sabouraud Dextrose Agar (SDA) medium and fungal inocula were prepared from 5-day-old cultures. Spore density of each strain was adjusted to $2 \times 10^{6}$ spores $/ \mathrm{ml}$ by microscopic enumeration of cell counting hematocytometer.

\section{Dual culture method}

In order to examine the antagonistic properties of a bacterial isolate against phytopathogenic fungi, the dual culture technique was used. This is the simplest method to detect antifungal activity. In this technique, an agar block ( $5 \mathrm{~mm}$ diameter) of 5-day-old culture of fungal pathogen was placed in the centre of a plate containing equal volume of Mueller-Hinton agar (MHA) and Sabouraud Dextrose agar (SDA). A loopful of 24-hour-old culture of the tested bacteria was inoculated at $2 \mathrm{~cm}$ next to the pathogen. The plates were incubated at $28 \pm 1^{\circ} \mathrm{C}$ for five days. The antagonistic activity was observed by inhibition of the growth of the pathogen towards the direction of bacterial isolate. The hyphal growth inhibition was classified into four levels: strong activity (+++, inhibition zone 11$20 \mathrm{~mm}$ ), moderate activity (++, inhibition zone $1-10 \mathrm{~mm}$ ), weak activity (+, fungal colony was close to the bacterial streak, but could not grow across the streak), and no activity (-, fungal colony was across the bacterial streak). All the experiments were carried out in triplicates.

\section{Disc diffusion method}

Disc diffusion method was also used to check the antifungal properties of the isolated bacterial strain against selected fungal pathogens. Petri plates containing equal volumes of MHA and SDA $(7.5+7.5 \mathrm{ml})$ medium were inoculated with a standardized bacterial isolate. A disc 
(Whatman no. 1 filter paper) containing $20 \mu \mathrm{l}$ of bacterial suspension was placed on a Petri plate pre-seeded with the fungal pathogen. Standard antimycotics - cycloheximide $\left(0.5 \mathrm{gL}^{-1}\right)$ and nystatine $\left(0.5 \mathrm{gL}^{-1}\right)$ - were used as positive control, while sterile distilled water was used as negative control. The plates were initially kept at $4^{\circ} \mathrm{C}$ for $2 \mathrm{~h}$ to allow the diffusion of the isolate, and later incubated at $28 \pm 1^{\circ} \mathrm{C}$. The zones of inhibition were measured after five days of incubation and the mean values were calculated. All the experiments were carried out in triplicates. The zone of inhibition between pathogen and the bacterial isolate was rated as significant $(+++)$ if the inhibition zone was $>10 \mathrm{~mm}$ wide, moderate $(++)$ if the zone of inhibition was 2 to $10 \mathrm{~mm}$ wide, and poor $(+)$ if it was $<2 \mathrm{~mm}$ wide.

\section{RESULTS AND DISCUSSION}

\section{Isolation and identification of bacterium}

From the compost samples, we had about 43 different bacterial isolates of suspected Grampositive bacteria, and each one of these isolates was preliminarily tested against the fungi Aspergilus ochraceus FNS- FCC 46, Aspergilus niger FNS- FCC 142, and Penicillium commune FNS- FCC 864 (later tested against phytopathogenic fungi) (Fig. 1). We had one bacterial isolate that had the best antifungal activities against the tested fungi.

Morphological studies showed that the isolates were Gram-positive, sporulating, rodshaped bacteria. Alignment of the 16S rRNA sequences of the bacterial isolate revealed identity of $99 \%$ to the genus Bacillus. The isolated strain DZ-3 obtained from a compost sample was identified as Paenibacillus alvei and thus named $P$. alvei strain DZ-3. Inoculated on MHA, P. alvei DZ-3 produced large, circular, rough, white-yellowish colonies with irregular margins.

\section{Dual culture method}

P. alvei DZ-3 that showed preliminary antifungal activity against the three fungi (Aspergilus ochraceus FNS- FCC 46, Aspergilus niger FNS- FCC 142, and Penicillium commune FNS- FCC 864) (Fig. 2), was taken to test its antifungal activity toward several phytopathogenic fungi (Fig. 3).

Test plates were observed for inhibition of fungal growth after five days. The inhibition zone between Paenibacillus alvei DZ-3 streak and the edge of fungal colony was then measured.

It was found that the antagonistic Paenibacillus alvei DZ-3 tested in this study exhibited only strong and moderate antifungal activities (Table 1). Alternaria alternata FNS- FCC 624 was the most susceptible, while Botrytis cinerea FNS- FCC 23 and Fusarium oxysporum FNS- FCC 103 were the most resistant to antagonistic Paenibacillus alvei DZ-3.

Although Paenibacillus alvei DZ-3 inhibited mycelial growth of the fungal pathogen on

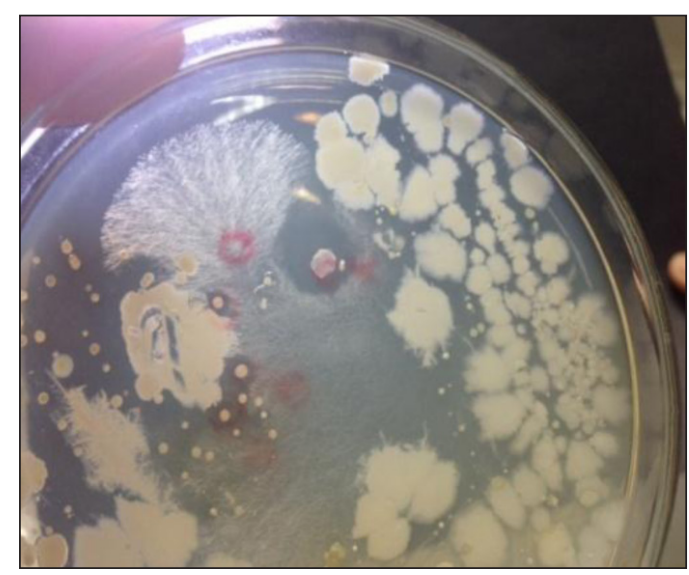

Fig. 1. Primary screening of bacteria from compost samples with antifungal activity

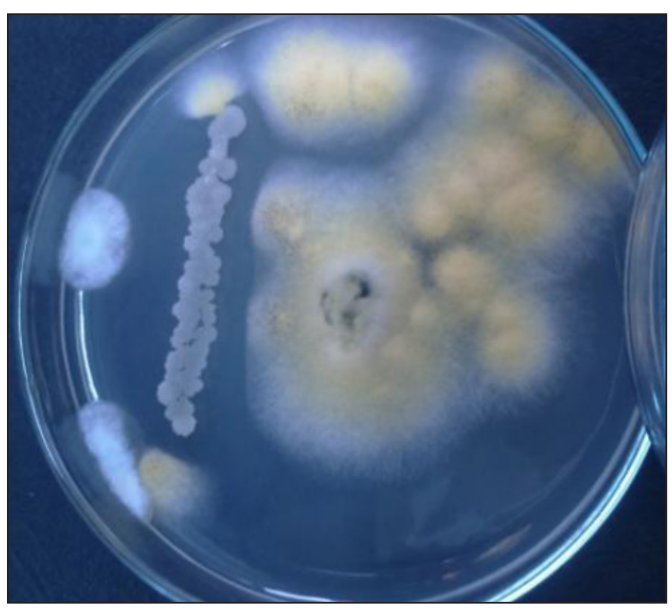

Fig. 2. The biological effect of Paenibacillus alvei DZ-3 on Aspergilus niger FNS- FCC 142 

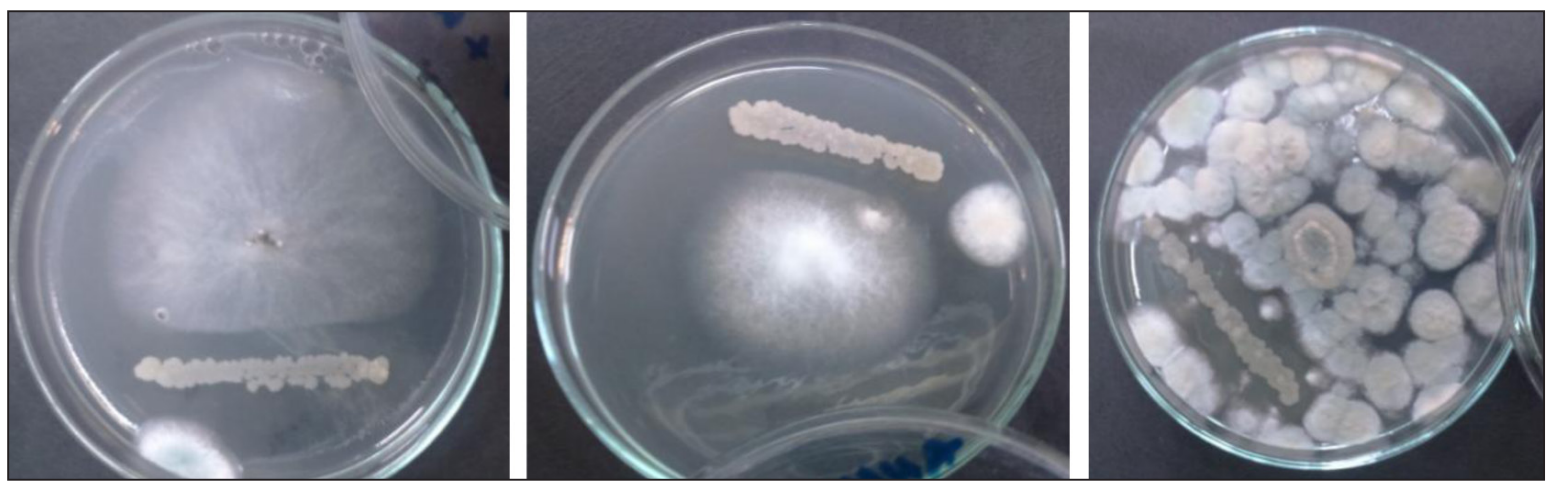

Fig. 3. The biological effect of Paenibacillus alvei DZ-3 on phytopathogenic Botrytis cinerea FNS- FCC 23, Fusarium oxysporum FNS- FCC 103, and Plasmopara viticola FNS- FCC 65

Table 1. The bioeffect of Paenibacillus alvei DZ-3 on the phytopathogenic fungi tested with the dual culture method

(All the experiments were carried out in triplicates; the mean values were calculated).

\begin{tabular}{c|c|c|c}
\hline Bacterial isolate & Phytopathogenic fungus & $\begin{array}{c}\text { Inhibition zone } \\
(\mathbf{m m})\end{array}$ & $\begin{array}{c}\text { Level of antifungal } \\
\text { activity }\end{array}$ \\
\hline & Botrytis cinerea FNS- FCC 23 & 5 & ++ \\
\cline { 2 - 4 } & Fusarium oxysporum FNS- FCC 103 & 5 & ++ \\
\cline { 2 - 4 } $\begin{array}{c}\text { Paenibacillus alvei } \\
\text { DZ-3 }\end{array}$ & Plasmopara viticola FNS- FCC 65 & 7 & ++ \\
\cline { 2 - 4 } & Alternaria alternata FNS- FCC 624 & 16 & +++ \\
\cline { 2 - 5 } & Aspergilus ochraceus FNS- FCC 46 & 10 & ++ \\
\cline { 2 - 4 } & Aspergilus niger FNS- FCC 142 & 7 & +++ \\
\cline { 2 - 4 } & Penicillium commune FNS- FCC 864 & 15 & ++ \\
\hline
\end{tabular}

Strong activity (+++, inhibition zone $11-20 \mathrm{~mm})$, moderate activity (++, inhibition zone $1-10 \mathrm{~mm})$

the agar plate, the antifungal activity was not mediated by the cell-to-cell contact. It is well known that a number of bacteria, especially from the genus Bacillus (Kumar et al., 2012) and Paenibacillus (Xu et al., 2014; Timmusk et al., 2009), can produce antibiotics, so we assumed that our isolate produced antibiotic substance which was diffused into the agar medium and caused inhibition of the growth of pathogen in the direction of bacterial isolate.

\section{Disc diffusion method}

The use of microorganisms and their secreted molecules to prevent plant diseases is considered an attractive alternative and a way to supplement synthetic fungicides for the management of plant diseases.
Generally, this screening is for the selection of the secondary metabolite with antifungal properties.

The antagonistic activity of Paenibacillus alvei DZ-3 against plant pathogenic fungi was assessed using the disc diffusion assay. Growth inhibition of phytopathogenic mycelia on culture plates was observed five days after inoculation. The strain produced the largest zone of fungal growth inhibition $(22 \mathrm{~mm})$ during the screening under in vitro conditions with $\mathrm{Al}$ ternaria alternata FNS- FCC 624. The antagonist strongly inhibited the development of all tested fungi (Table 2) compared to two antimycotics (nystatine and cycloheximide).

The results of in vitro assays showed that Paenibacillus alvei DZ-3 had a strong fungicidal 
Table 2. The bioeffect of Paenibacillus alvei DZ-3 on tested phytopathogenic fungi with disc diffusion method

(All the experiments were carried out in triplicates; the mean values were calculated).

\begin{tabular}{c|c|c|c|c}
\hline \multirow{2}{*}{$\begin{array}{c}\text { Phytopathogenic } \\
\text { fungus }\end{array}$} & \multicolumn{5}{|c}{ Inhibition zone (mm) } \\
\cline { 2 - 5 } & $\begin{array}{c}\text { Paenibacillus } \\
\text { alvei DZ-3 }\end{array}$ & $\begin{array}{c}\text { + positive control } \\
\left(\mathbf{0 . 5} \mathrm{gL}^{-1} \text { nystatine }\right)\end{array}$ & $\begin{array}{c}\text { + positive control } \\
\left(\mathbf{0 . 5} \mathrm{gL}^{-1} \text { cycloheximide }\right)\end{array}$ & $\begin{array}{c}\text { - negative con- } \\
\left.\text { trol (sd } \mathrm{H}_{2} \mathrm{O}\right)\end{array}$ \\
\hline $\begin{array}{c}\text { Botrytis cinerea } \\
\text { FNS- FCC 23 }\end{array}$ & 10 & 5 & 7 & 0 \\
\hline $\begin{array}{c}\text { Fusarium oxysporum } \\
\text { FNS- FCC 103 }\end{array}$ & 10 & 5 & 8 & 0 \\
\hline $\begin{array}{c}\text { Plasmopara viticola } \\
\text { FNS- FCC 65 }\end{array}$ & 14 & 6 & 6 & 0 \\
\hline $\begin{array}{c}\text { Alternaria alternata } \\
\text { FNS- FCC 624 }\end{array}$ & 22 & 6 & 7 & 0 \\
\hline $\begin{array}{c}\text { Aspergilus ochraceus } \\
\text { FNS- FCC 46 }\end{array}$ & 17 & 5 & 5 & 0 \\
\hline $\begin{array}{c}\text { Aspergilus niger } \\
\text { FNS- FCC 142 }\end{array}$ & 15 & 5 & 6 & 0 \\
\hline $\begin{array}{c}\text { Penicillium commune } \\
\text { FNS- FCC 864 }\end{array}$ & 20 & 5 & 9 & 0 \\
\hline
\end{tabular}

Significant activity $(+++$, inhibition zone $>10 \mathrm{~mm})$; moderate activity $(++$, inhibition zone $2-10 \mathrm{~mm})$; poor activity $(+$, inhibition zone $<2 \mathrm{~mm})$

effect against phytopathogenic fungus on a Petri plate against two tested antimycotics that showed poor antifungal activity.

It has been mentioned by numerous researches of recent years that many species of the Gram-positive Paenibacillus bacteria showed in vitro antagonistic activities against several fungal phytopathogens belonging to the ascomycetes, basidiomycetes, and oomycetes (Lee et al., 2008) (Fig. 4).

There are many different kinds of Gram-positive and Gram-negative bacteria (such as Bacillus spp. and Pseudomonas spp.) that have antifungal activities toward different fungi, especially the phytopathogenic fungi (Kobayashi et al., 2000; Gupta et al., 2001). To this group we can add our
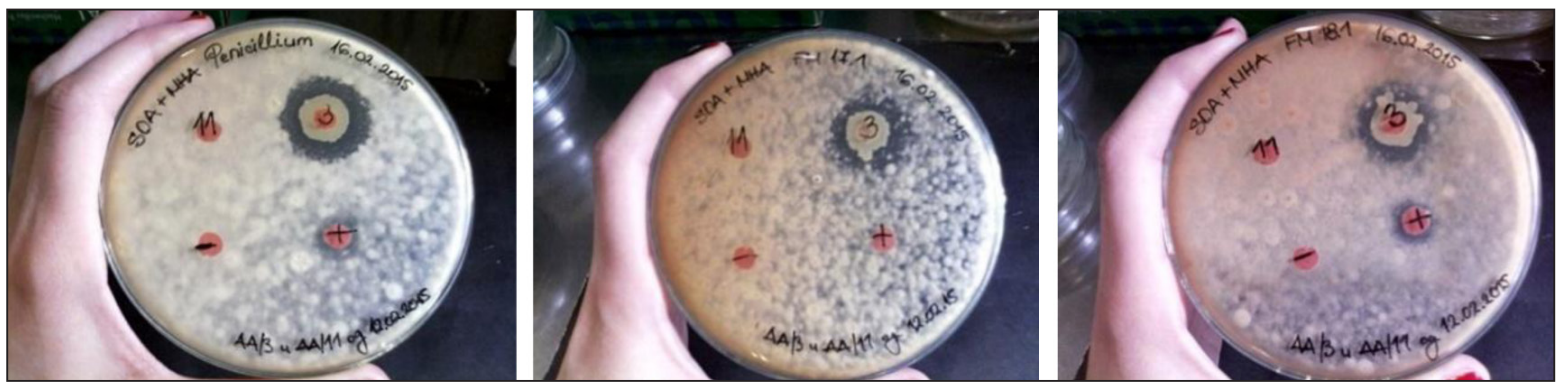

Fig. 4. In vitro antagonistic activity of Paenibacillus alvei DZ-3 against Penicillium commune FNS- FCC 864, Aspergilus ochraceus FNS- FCC 46, and Aspergilus niger FNS- FCC 142, assessed with the disc diffusion assay. Photographs were taken after five days of incubation at $28^{\circ} \mathrm{C}$

11 - positive control (0.5 gL-1 nystatine); 3 - Paenibacillus alvei DZ-3; + positive control (0.5 $\mathrm{gL}^{-1}$ cycloheximide); - negative control $\left(\mathrm{sd}_{2} \mathrm{O}\right)$ 
antifungal isolate Paenibacillus alvei DZ-3, which showed a wide range of antifungal activities toward phytopathogenic fungi.

This isolate might represent a good alternative as a biological control agent toward plant pathogenic fungi. The antifungal activities were due to the production of an extracellular antifungal metabolites or antimycotics that could be extracted for purification or for further studies.

\section{CONCLUSIONS}

In the course of screening for microorganisms with the potential to be used as biocontrol agents, Paenibacillus alvei DZ-3 was identified as having a potent antifungal activity against several phytopathogen fungi. According to in vitro tests, Paenibacillus alvei DZ-3 showed the inhibition zone of significant activity. Although specific antifungal substances produced by Paenibacillus alvei DZ-3 remain to be identified, this strain has the potential to be a useful agent for biological control of the mentioned fungi.

Received 21 May 2017 Accepted 26 October 2017

\section{References}

1. Ash C, Priest FG, Collins MD. Molecular identification of rRNA group 3 bacilli (Ash, Farrow, Wallbanks and Collins) using a PCR probe test. Proposal for the creation of a new genus Paenibacillus. Ant Van Leeuwen. 1993; 64: 253-60.

2. Berge $\mathrm{O}$, Guinebretiere MH, Achouak W, Normand P, Heulin T. Paenibacillus graminis sp. nov. and Paenibacillus odorifer sp. nov., isolated from plant roots, soil and food. Int J Syst Evol Microbiol. 2002; 52: 607-16.

3. Compant S, Duffy B, Nowak J, Clément Ch, Ait Barka E. Use of plant growth-promoting bacteria for biocontrol of plant diseases: principles, mechanisms of action, and future prospects. Appl Environ Microbiol. 2005; 71(9): 4951-9.
4. Eziashi E, Omamor IB, Odigie EE. Antagonism of Trichoderma viride and effects of extracted water soluble compounds from Trichoderma species and benlate solution on Ceratocystis paradoxa. Afr J Biotechnol. 2007; 6: 388-92.

5. Fortes TO, Alviano DS, Tupinambá G. Production of an antimicrobial substance against Cryptococcus neoformans by Paenibacillus brasilensis Sa3 isolated from the rhizosphere of Kalanchoe brasoloensis. Microbiol Res. 2008; 163: 200-7.

6. Garbeva P, van Veen JA, van Elsas JD. Predominant Bacillus spp. in agricultural soil under different management regimes detected via PCRDGGE. Microb Ecol. 2003; 45: 302-16.

7. Gupta CP, Dubey RC, Kang SC, Maheshwari DK. Antibiosis-mediated necrotrophic effect of Pseudomonas GRC2 against two fungal plant pathogens. Current Science. 2001; 81(1): 91-4.

8. He ZG, Kisla D, Zhang LW, Yuan CH, GreenChurch KB, Yousef AE. Isolation and identification of a Paenibacillus polymyxa strain that coproduces a novel lantibiotic and polymyxin. Appl Environ Microbiol. 2007; 73: 168-78.

9. Kobayashi K, Laura G, Ana V, Jorge YC. Suppressive effects of antagonistic bacteria and metabolites on a pathogenic Rhizoctonia sola$n i$ strain. Increased production in a specific medium. RIA. 2000; 29(2): 63-75.

10. Kumar P, Satyajeet Kh, Dubey RC. Diversity of bacilli from disease suppressive soil and their role in plant growth promotion and yield enhancement. New York Science Journal. 2012; $5(1)$.

11. Lee YK, Senthilkumar M, Kim JH, Swarnalakshmi K, Annapurna K. Purification and partial characterization of antifungal metabolite from Paenibacillus lentimorbus WJ5. World J Microbiol and Biotechnol. 2008; 24(12): 3057-62.

12. Liu WW, Mu W, Zhu BY, Du YC, Liu F. Antagonistic activities of volatiles from four strains of Bacillus spp. and Paenibacillus spp. against soil-borne plant pathogens. Agric Sci China. 2008; 7: 1104-14. 
13. Raza W, Yang W, Shen QR. Paenibacillus polymyxa: antibiotics, hydrolytic enzymes and hazard assessment. J Plant Pathol. 2008; 90: 419-30.

14. Timmusk SP, van West NAR, Huffstutler RP. Paenibacillus polymyxa antagonizes oomycete plant pathogens Phytophthora palmivora and Pythium aphanidermatum. Journal of Applied Microbiology. 2009; 106: 1473-81.

15. von der Weid I, Duarte GF, van Elsas JD, Seldin L. Paenibacillus brasilensis sp. nov., a novel nitrogen-fixing species isolated from the maize rhizosphere in Brazil. Int J Syst Evol Microbiol. 2002; 52: 2147-53.

16. von der Weid I, Alviano DS, Santos ALS, Soares RMA, Alviano CS, Seldin L. Antimicrobial activity of Paenibacillus peoriae strains NRRL BD-62 against a broad spectrum of phytopathogenic bacteria and fungi. J Appl Microbiol. 2003; 95: 1143-51.

17. von der Weid I, Artutsson V, Seldin L, Jansson JK. Antifungal and root surface colonization properties of GFP-tagged Paenibacillus brasilensis PB177. World J Microbiol Biotechnol. 2005; 12: 1591-7.

18. Xu SJ, Hong SJ, Woobong Ch, Byung SK. Antifungal activity of Paenibacillus kribbensis strain T-9 isolated from soils against several plant pathogenic fungi. Plant Pathol. J. 2014; 30(1): 102-8.

19. Yoon JH, Oh HM, Yoon BD, Kang KH, Park YH. Paenibacillus kribbensis sp. nov. and Paenibacillus terrae sp. nov., bioflocculants for efficient harvesting of algal cells. Int J Syst Evol Microbiol. 2003; 53: 295-301.

\section{Natalija Atanasova-Pancevska, Dzoko Kungulovski}

\section{PAENIBACILLUS ALVEI DZ-3 KAIP BIOKONT- ROLĖS AGENTO PRIEŠ KELIS FITOPATOGE- NINIUS GRYBUS POTENCIALAS IN VITRO}

\section{Santrauka}

Grybeliniai fitopatogenai sukelia didelius nuostolius daugeliui ekonomiškai svarbių pasèlių ir daržovių. Didesnių fungicidų dozių naudojimas šių patogenų kontrolei ne tik padidina gamybos sąnaudas, bet ir daro didelę žalą aplinkai. Straipsnio tikslas yra ịvertinti in vitro aplinkai nekenksmingą kai kurių grybinių fitopatogenų kontrolès būdą. Šiame tyrime iš komposto mėginių išskirtas bakterijų štamas DZ-3, pasižymintis stipriu priešgrybeliniu aktyvumu, buvo identifikuotas kaip Paenibacillus alvei pagal morfologines ir taksonomines savybes bei 16S rRNR geno sekų analizę. Nustatyta, kad Paenibacillus alvei DZ-3 gali būti biokontrolès agentu îvairiems fitopatogeniniams grybams.

Raktažodžiai: fitopatogenas, Paenibacillus alvei, priešgrybelinis aktyvumas, kompostas 